\title{
A new species of the family Polydesmidae (Diplopoda: Polydesmida) from Vietnam
}

\author{
Nguyen Duc Anh \\ Institute of Ecology and Biological Resources, 18, Hoangquocviet Rd., Caugiay, Hanoi, Vietnam. \\ E-mail: ducanh410@yahoo.com / ducanh@iebr.ac.vn
}

\begin{abstract}
Polydesmus vietnamicus sp. nov. is described from northern Vietnam. The new species is closely related to a geographically relatively remote congener $P$. liber Golovatch, 1991, from Hong Kong, China, differing in minor details of gonopod structure.
\end{abstract}

\section{Keywords}

Vietnam, Polydesmidae, Polydesmus, new species

\section{Introduction}

Polydesmidae is almost strictly Holarctic, encompassing more than 60 nominal genera or subgenera and nearly 400 species and subspecies (Hoffman 1980, Golovatch 1991). Most species are found in the Mediterranean area, whereas Central and East Asia, as well as the entire Nearctic region, have lower generic, and to a lesser degree, species diversity (Golovatch 1991, Djursvoll et al. 2001).

Larger species of Polydesmidae seem to be particularly rare in Asia. The family is only represented there by a few species of the diverse, mainly East Asian genus Epanerchodus Attems, 1901 from southern and eastern China, Japan and the Korean peninsula (Golovatch 1991, Murakami 1968, Mikhaljova \& Lim 2006); by three species of Pacidesmus Golovatch, 1991 in southern China and one more in northern Thailand (Golovatch 1991, Golovatch \& Geoffroy 2006); and by one species each in Usbekodesmus Lohmander, 1933 and Polydesmus Latreille, 1802/1803 from southern China (Golovatch 1991, Geoffroy \& Golovatch 2004, Golovatch \& Geoffroy 2006, Golovatch et al. 2007). Unlike Pacidesmus which seems to be endemic to the East 
Asian region, Usbekodesmus also has several species in Central Asia and the Himalayas of Nepal. Polydesmus is certainly the largest genus in the family, with over 200 species and subspecies known, mainly in Europe and the Mediterranean west of the central Caucasus (Hoffman 1980, Djursvoll et al. 2001), plus four in Japan: Polydesmus japonicus Miyosi, 1956, P. miyosii Murakami, 1966, P. tanakai Murakami, 1970 and P. tangonis Murakami, 1973; two in eastern China: P. moorei Pocock, 1895, P. paludicola Pocock, 1895; and one, P. liber Golovatch, 1991, in Hong Kong, southern China (Golovatch 1991). The distribution of Polydesmus therefore seems to be amphiPalearctic (Golovatch, 1991).

Although Vietnam is known to support a very rich millipede fauna (Enghoff et al. 2004), no species of the family Polydesmidae has heretofore been recorded in this country. The gap between southern China and Thailand has now been filled with a new species of Polydesmidae, described below. The new species is closest to its geographically relatively remote congener, P. liber Golovatch, 1991, from Hong Kong.

All type material has been deposited in the collection of the Institute of Ecology and Biological Resources (IEBR) in Hanoi, Vietnam.

\section{Taxonomy}

\section{Order POLYDESMIDA Pocock, 1887 \\ Family Polydesmidae Leach, 1815 \\ Genus Polydesmus Latreille, 1802/1803}

Polydesmus vietnamicus sp. nov.

Figs 1-5.

Holotype: 1 male, Vietnam, Vinhphuc Province, Tamdao National Park, 100 km northwest of Hanoi, secondary subtropical forest, $1000 \mathrm{~m}$ a.s.l., $21^{\circ} 27^{\prime} 22^{\prime \prime} \mathrm{N}$; $105^{\circ} 38^{\prime} 50^{\prime \prime} \mathrm{E}, 1$ October 2005, leg. Nguyen Duc Anh. - Paratypes: 1 female, same data, together with holotype; 1 female, same locality, head damaged, 22 March 2005, leg. Nguyen Duc Anh.

Diagnosis: A typical polydesmid with 20 body rings and three transverse rows of bosses with setae on metaterga. Gonopodal solenomere rather well-developed, conspicuously shaped. Endomere very long and strongly falcate, directed caudally, starting laterally and basally of recurvature point of seminal groove, set off from femorite by a sulcus. Seminal groove largely mesal, crossing femorite diagonally, terminal lateral loop relatively short and turning around a distofemoral process. Differs from morphologically closely related Polydesmus liber Golovatch, 1991 in the larger size and gonopod endomere with a pair of teeth at about its midlength.

Description: Holotype male ca $33.2 \mathrm{~mm}$, width of midbody pro- and metaterga 2.8 and $5.4 \mathrm{~mm}$, respectively. Corresponding measurements for female paratypes: ca. $38.4 \mathrm{~mm}$ in length, width of midbody pro- and metaterga 3.0 and $6.0 \mathrm{~mm}$, respectively. 

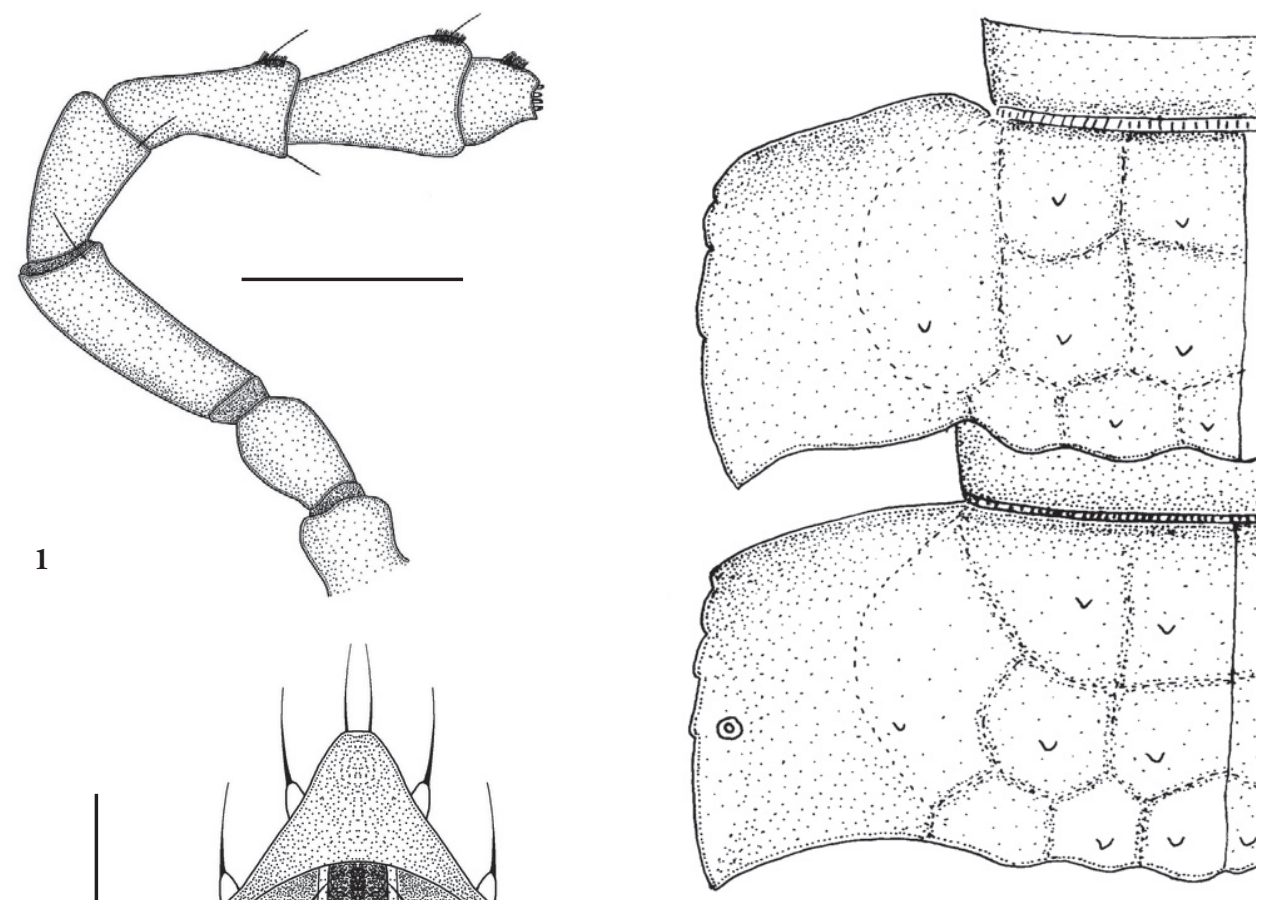

2

3
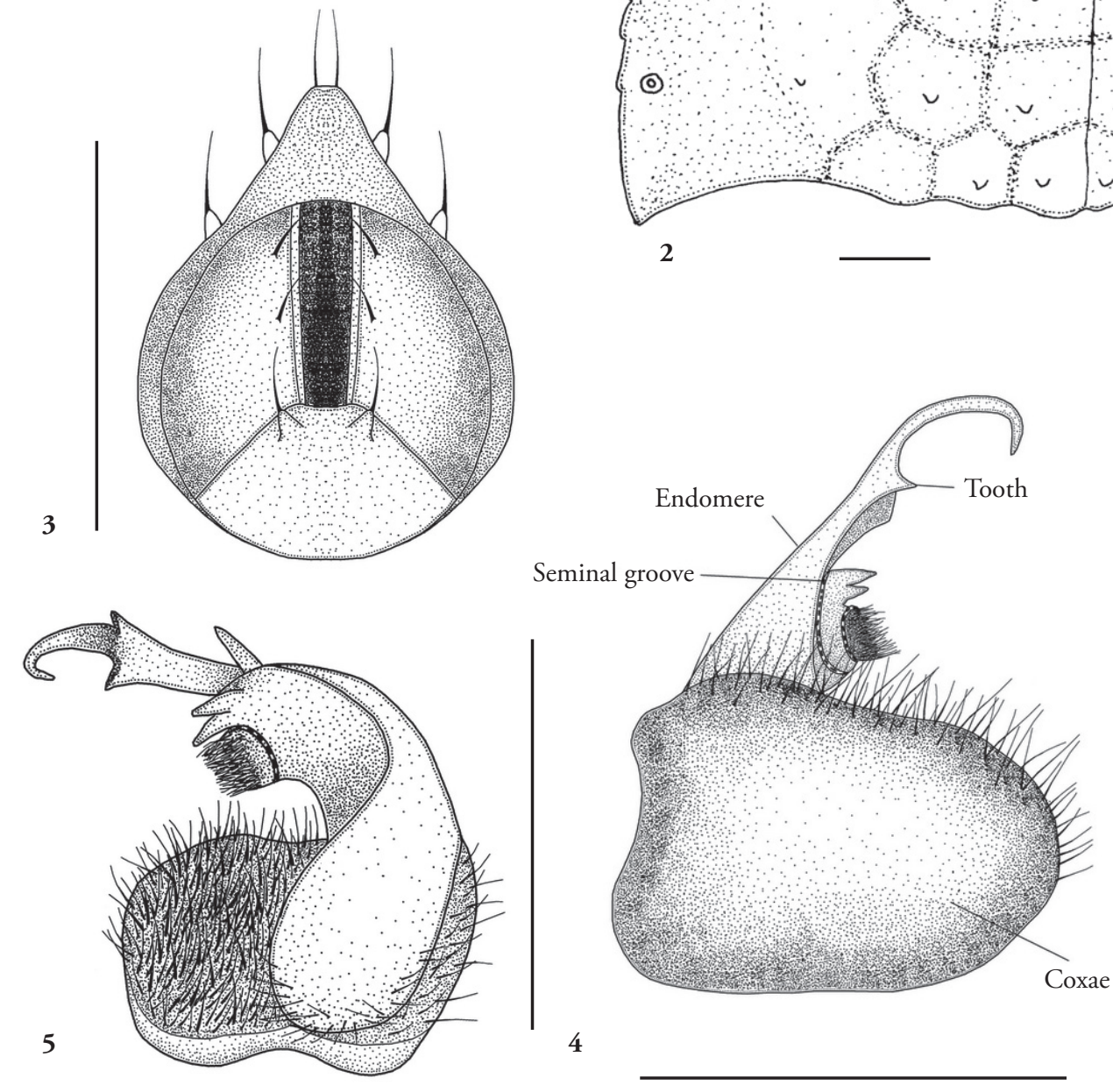

Figures 1-5. Polydesmus vietnamicus sp. nov., right antenna (1); segments 8-9, dorsal view (2); telson, ventral view (3); right gonopod, lateral view (4) and posterio-mesal view (5). Scale lines $=1 \mathrm{~mm}$ 

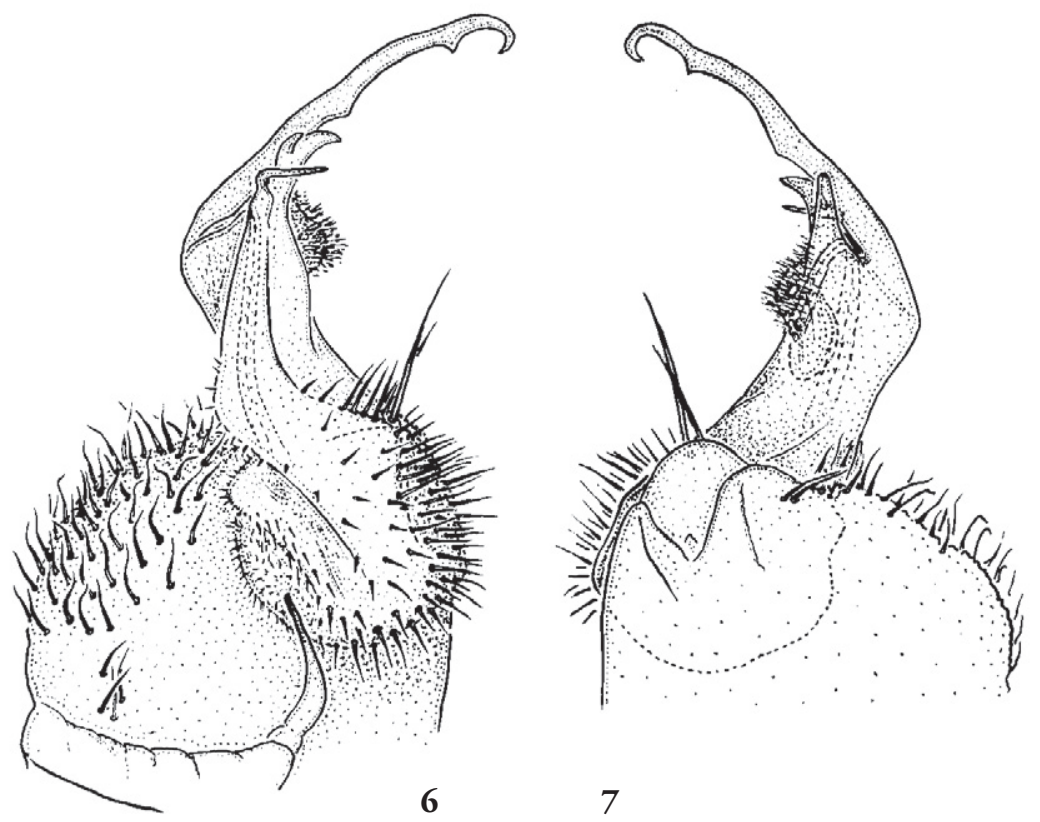

0.5

Figures 6-7. Polydesmus liber Golovatch, 1991, gonopod, mesal view (6), lateral view (7). Scale $0.5 \mathrm{~mm}$ (After Golovatch 1991)

Male: Coloration generally pale gray-yellowish. Lateral parts of paraterga yellow, their basal parts like the metaterga pale gray-yellowish with some yellow spots. Antennae, legs and sterna yellow.

Head a little broader than collum, densely setose below antennal sockets. Frons rather smooth, a little convex, with fine microgranulation. Epicranial suture very deep and evident, dividing frons into two inflated polygons.

Antennae rather slender, clavate; in situ reaching the posterior end of ring 2. Length of antennomeres $3>4 \approx 5 \approx 6>2>7$ (Fig. 1). Antennomeres 5 and 6 each with a distodorsal group of minute bacilliform sensilla, antennomere 7 with a dorsal parabasal knob.

Body of typical polydesmoid form, adults with 20 rings (18 podous +1 apodous ring + Telson). Body gently and gradually broadening until ring 6 , thence parallel-sided up to ring 14, onward first gradually and delicately, but from ring 17 abruptly tapering. Dorsum a little convex and rather flattened in lateral view, posteriormost rings somewhat more convex.

Paraterga small and subtriangular on collum and ring 2, well-developed on subsequent rings, subrectangular on rings 3-10, parallelogram-shaped on rings 11-17, subhorizontal, elevated a little above dorsum; distinctly rimmed anteriorly; collum with one lateral incision, rings $2-4$ and other pore-bearing rings with four incisions, poreless rings with three indentations; incision somewhat better developed on several anteriormost rings. 
Anterior corner of paraterga 2 strongly acuteangular while of paraterga 3 and 4 slightly squared, subsequent paraterga slightly obtuse. Rear corner of paraterga 2-5 somewhat acutangular, thereafter rear corner strongly acutangular, beak-like pointed, increasingly projecting caudad beyond hind tergal contour, slightly so until rings 14, more so onward, clearly so on ring 19. Ozopore formula normal, pores dorsolateral, placed near last paratergal indentation at about $1 / 3$ of paratergal width.

Metaterga with three transverse rows of well-developed, polygonal bosses (Fig. 2). Metatergal setae minute, bacilliform, somewhat longer and more distinct on metaterga 18 and 19. Limbus finely but distinctly spinulate.

Metatergal surface smooth, finely shagreened. Waist between pro- and metazona deep, evident and with fine longitudinal striations, reduced laterad. Pleurites dull. Pleurosternal carinae absent.

Epiproct short, broadly truncated and a little curved down, with two long setae at tip. Paraprocts semi-circular; hypoproct subtrapeziform (Fig. 3). Legs rather long and slender, somewhat incrassate compared to those of female, devoid of sphaerotrichomes. Prefemora swollen dorsally.

Sterna without processes, densely and delicately setose.

Gonopod coxae large, subglobose, without setae on lateral side, but with dense long setae at distal edges and on mesal side. Telopodite suberect; its basal, prefemoral part typically densely setose. Endomere subfalcate, high, approximately $1 / 2$ full length of telopodite, set off from femorite by a suture, with a pair of strong teeth at about midway, tip curved down, unciform. Seminal groove running along mesal side dorsolaterad, loop lying laterally before terminating in a well-developed accessory seminal chamber provided with a hairy pulvillus at base of solenomere. The latter short but evident, bifid, with a well-developed, oblique, additional spine (Figs 4-5).

Female. Slightly larger than male, up to $38.4 \mathrm{~mm}$ long. Paraterga slightly less strongly developed. Legs unmodified, somewhat shorter and more slender. Vulvae highly elevated. Epigynial ridge low.

Etymology: The name vietnamicus refers to the terra typica.

Remarks. As can be seen in Figures 6-7, this new species is similar in gonopod shape to Polydesmus liber Golovatch, 1991 from Hong Kong, China. Both species have similar densely setose gonocoxae, devoid of sphaerotrichomes on legs, simple endomere in comparison with other Polydesmus species. Differences between the two species are:

\begin{tabular}{l|l}
\hline Polydesmus vietnamicus sp. nov. & Polydesmus liber Golovatch, 1991 \\
\hline Body length $33-38.4 \mathrm{~mm}$ & Body length $21-23 \mathrm{~mm}$ \\
\hline $\begin{array}{l}\text { Gonopod endomere with only a pair of } \\
\text { teeth at about midlength. }\end{array}$ & $\begin{array}{l}\text { Gonopod endomere with two pairs of moderate } \\
\text { teeth at about } 1 / 3 \text { and } 2 / 3 \text { of its length. }\end{array}$ \\
\hline
\end{tabular}




\section{Acknowledgments}

I am grateful to Dr. Sergei I. Golovatch, Institute for Problems of Ecology and Evolution, Russian Academy of Sciences (Moscow) for his help and valuable advices in preparing the paper. I also thank Dr. Robert Mesibov (Queen Victoria Museum and Art Gallery, Australia) for improving the advanced manuscript. My participation at the 14th International Congress of Myriapodology, Görlitz (Germany) was financially supported by the Ministry of Sciences and Technology (MOST), Vietnam, Prof. Dr. Henrik Enghoff (University of Copenhagen, Denmark), and the Staatliches Museum für Naturkunde Görlitz.

\section{References}

Djursvoll, P., Golovatch, S.I., Johanson, K.A., \& Meidell, B. (2001) Phylogenetic relationships within Polydesmus sensu lato (Diplopoda: Polydesmidae). - Fragmenta Faunistica 43 (Suppl.): 37-59 (for 2000).

Enghoff, H., Golovatch, S.I. \& Nguyen, D.A. (2004) A review of the millipede fauna of Vietnam. - Arthropoda Selecta 13 (1/2): 25-43.

Geoffroy, J.-J. \& Golovatch, S.I. (2004) Some polydesmidan millipedes from caves in southern China (Diplopoda: Polydesmida), with descriptions of four new species. - Arthropoda Selecta 13 (1-2): 19-28.

Golovatch, S.I. (1991) The millipede family Polydesmidae in Southeast Asia, with notes on phylogeny (Diplopoda: Polydesmida). - Steenstrupia 17 (4): 141-159.

Golovatch, S.I. \& Geoffroy, J-.J. (2006) Review of the Southeast Asian millipede genus Pacidesmus Golovatch, with the description of a new troglobitic species from southern China (Diplopoda, Polydesmida, Polydesmidae). - Zootaxa 1325: 363-368.

Golovatch, S.I., Geoffroy, J-.J. \& Mauriès, J.-P. (2007) Several new or poorly-known cavernicolous millipedes from southern China. - Arthropoda Selecta 15 (2): $81-89$ (for 2006).

Hoffman, R.L. (1980) Classification of the Diplopoda. Muséum d'Histoire Naturelle, Genève, 237 pp. (for 1979).

Mikhaljova, E. \& Lim, K.-Y. (2006) The millipede genus Epanerchodus Attems, 1901 in the Korean Peninsula, with a description of a new species (Diplopoda, Polydesmida, Polydesmidae). - Zootaxa 1350: 45-53.

Murakami, Y. (1968) Two new millipeds of the genus Epanerchodus from Japanese caves. - Annotationes zoologicae Japonenses 41 (4): 163-167. 